\title{
ЗАСТОСУВАННЯ ЗАХОДІВ АДМІНІСТРАТИВНОӦ ВІДПОВІДАЛЬНОСТІ ЗА ВЧИНЕННЯ ПРАВОПОРУШЕНЬ У СФЕРІ ЗАХИСТУ ДОВКІЛЛЯ В УКРАЇНІ : СТАН ТА ПЕРСПЕКТИВИ ПРАВОВОГО РЕГУЛЮВАННЯ
}

Хижня Л. $\epsilon$.

Акцентовано, що визначення сутності адміністративної відповідальності у сфері охорони довкілля вимагає застосування дедуктивного методу наукового пізнання, що дає змогу слідувати від розуміння загальної категорії до спеціальних іï складників. Наголошено, що розуміння сутності адміністративної відповідальності у сфері захисту довкілля має головною проблемою бланкетний характер відповідних норм адміністративного законодавства як регулятора відповідних суспільних відносин. Визначено, що підставами адміністративної відповідальності у сфері захисту довкілля є вчинення порушення норм адміністративно-деліктного законодавства України. Встановлено, що до системи чинного законодавства з питань застосування заходів адміністративної відповідальності у сфері захисту довкілля належать міжнародно-правові акти та договори, ратифіковані Верховною Радою України. Здійснено аналіз положень Декларації з проблем навколишнього середовища, прийнятої на засіданні Організації Об'єднаних Націй у Стокгольмі у 1972 році. Встановлено, що у Декларації вперше зроблено акцент на розумінні «довкілля» як природного, так і антропогенного, тобто створеного людиною, при цьому наголошується, що має бути забезпечена безпека не лише природних ресурсів та об'єктів, але й іншого оточуючого людину середовища.

Ключові слова: адміністративне правопорушення, довкілля, об'єкт, природні ресурси, суб'єкти, фізичні особи, юридичні особи.

Акцентировано, что определение сущности административной ответственности в области охраны окружающей среды требует применения дедуктивного метода научного познания, позволяющего следовать от понимания общей категории до специальных её составляющих. Отмечено, что в понимании сущности административной ответственности в сфере защиты окружающей среды главной проблемой является бланкетный характер соответствующих норм административного законодательства как регулятора данных общественных отношений. Определено, что основаниями административной ответственности в сфере защиты окружающей среды является совершение нарушения норм административно-деликтного законодательства Украины. Установлено, что к системе действующего законодательства по вопросам применения мер административной ответственности в сфере защиты окружающей среды относятся международно-правовые акты и договоры, ратифицированные Верховной Радой Украины. Осуществлён анализ положений Декларации по проблемам окружающей среды, принятой на заседании Организации Объединённых Наций в Стокгольме в 1972 году. Установлено, что в Декларации впервые сделан акцент на понимании термина «окружающая среда» как естественной, так и антропогенной, то есть созданной

Хижня Л. Є., 2019 человеком, при этом отмечается, что должна быть обеспечена безопасность не только природных ресурсов и объектов, но и другой окружающей человека среды.

Ключевые слова: административное правонарушение, окружающая среда, объект, природные ресурсы, субъекты, физические лица, юридические лица.

It is emphasized that the definition of the essence of administrative responsibility in the field of environmental protection requires the use of a deductive method of scientific knowledge, which allows one to follow from understanding the general category to its special components. It is noted that understanding the essence of administrative responsibility in the field of environmental protection has the main problem of its blanket nature of the relevant norms of administrative law as a regulator of relevant public relations. It is determined that the basis of administrative responsibility in the field of environmental protection is a violation of the administrative-tort legislation of Ukraine. It has been established that the current legislation on the application of administrative responsibility measures in the field of environmental protection includes international legal acts and treaties ratified by the Verkhovna Rada of Ukraine. The analysis of the provisions of the Declaration on Environmental Issues adopted at the United Nations meeting in Stockholm in 1972 was carried out. It was established that the Declaration for the first time focused on the understanding of the "environment" as natural, as well as man-made, that is, created by man, and it is noted that the safety of not only natural resources and objects, but also other human environment should be ensured. It was emphasized that the application of measures of administrative responsibility for committing offenses in the field of environmental protection provides for the application of regulatory legal provisions not only of legislative level, but also of a subordinate nature, which should be classified according to the subject of publication; legal content; on the subject of legal regulation. It is noted that it is necessary to solve the problem of harmonization of domestic legislation on the application of administrative responsibility measures in accordance with international and European standards. It was emphasized that the implementation of activities to systematize administrative-tort legislation is aimed at helping to improve the effectiveness of law enforcement and enforcement, which has the inevitable result of the formation of an appropriate level of legal culture and legal activity of the public.

Key words: administrative offense, environment, object, natural resources, subjects, individuals, legal entities.

Постановка проблеми та їі актуальність. Визначення нормативно-правових засад застосування адміністративної відповідальності у сфері захисту довкілля вирішує стратегічне завдання захисту та охорони навколишнього природного середовища, $\epsilon$ базисом забезпечення раціонального використання природних ресурсів, $\epsilon$ пріоритетною основою впровадження концепції 
сталого розвитку, що $€$ загальновизнаним міжнародно-правовим стандартом розбудови взаємин людини і природи.

Ступінь розробленості проблеми. Дослідження проблематики забезпечення ефективності адміністративно-правового регулювання суспільних відносин загалом і з питань застосування адміністративної відповідальності за вчинення порушень у сфері захисту довкілля зокрема було в різні часи предметом наукових досліджень В.Б. Авер'янова, Ю.П. Битяка, Д.М. Бахраха, Ю.Н. Старилова, О.І. Остапенко, Т.О. Коломоєць, В.К. Колпакова, А.Т. Комзюка, О.В. Кузьменко, Ю.О. Легези, І.П. Голосніченка, М.Ф. Стахурського, Н.І. Золотарьової, С.Г. Стеценка та ін.

Метою дослідження $є$ визначення сучасного стану та перспектив удосконалення системи правового регулювання застосування заходів адміністративної відповідальності за вчинення порушень у сфері захисту довкілля.

Виклад основного матеріалу. О.А. Улютіна підкреслює, що реалізація адміністративно-правового регулювання відносин у галузі використання природних ресурсів має відбуватися в межах взаємодії органів виконавчої та законодавчої влади, громадянського суспільства та природи, що забезпечує стратегію і тактику охорони навколишнього природного середовища й раціонального природокористування [1, с. 19].

На підставі загальновизнаних критеріїв класифікації системи нормативно-правових актів України за територією дії необхідно виділити акти, що застосовуються на території України (зокрема, Закон України від 28 лютого 2019 року № 2697-VIII «Про Основні засади (стратегію) державної екологічної політики України на період до 2030 року» [2]), та акти, застосування яких обмежується певним регіоном. До останньої групи необхідно віднести такі нормативно-правові акти, як Закон України від 18 листопада 1997 року № 637/97-ВР «Про державне регулювання видобутку, виробництва і використання дорогоцінних металів і дорогоцінного каміння та контроль за операціями з ними» [3], Гірничий закон України від 6 жовтня 1999 року № 1127-XIV [4], Закон України від 10 лютого 2000 року № 1436-ІІІ «Про заборону на проведення суцільних рубок у гірських ялицево-букових лісах Карпатського регіону» [5] та ін.

Виділяються i регіональні природоресурсні програмні документи (зокрема, такими актами у Дніпропетровській області $€$ Програма створення і використання матеріальних резервів для запобігання, ліквідації надзвичайних ситуацій техногенного та природного характеру та їх наслідків у Дніпропетровській області до 2022 року», затверджена рішенням Дніпропетровської обласної ради від 24 квітня 2003 року № 137-8/XXIV [6], регіональна програма, спрямована на вирішення екологічних проблем Кривбасу та поліпшення стану навколишнього природного середовища на 2011-2022 роки, що затверджена рішенням Дніпропетровської обласної ради від 29.04.2011 №110-6/VI [7] та ін.).

Ю.О. Легеза виділяє у системі нормативно-правових актів з питань охорони довкілля акти, що діють на території окремого об'єкта [8, с. 90-93], і прикладом реалізації такого критерію класифікації $€$ Закон України від 27 лютого 1991 р. «Про правовий режим території, що зазнала радіоактивного забруднення внаслідок Чорнобильської катастрофи» [9], Закон України від 28 лютого
1991 р «Про статус і соціальний захист громадян, які постраждали внаслідок Чорнобильської катастрофи» [10], Закон України від 08 лютого 1995 р. «Про використання ядерної енергії та радіаційну безпеку» [11], Закон України від 20 червня 1997 р. «Про формування Фонду для здійснення заходів щодо ліквідації наслідків Чорнобильської катастрофи та соціального захисту населення» [12] тощо.

До системи нормативно-правового регулювання застосування заходів адміністративної відповідальності належать і міжнародні нормативно-правові акти, що у встановленому чинним законодавством порядку ратифіковані Верховною Радою України (ч. 1 ст. 9 Конституції України) [13].

У сфері захисту довкілля необхідно виділити такі міжнародні акти, що ратифіковані Верховною Радою України, як Декларація з проблем навколишнього середовища, прийнята на засіданні Організації Об'єднаних Націй у Стокгольмі у 1972 році [14]. У Декларації вперше зроблено акцент на розумінні «довкілля» як природного, так і антропогенного, тобто створеного людиною, при цьому наголошується, що має бути забезпечена безпека не лише природних ресурсів та об'єктів, але й іншого оточуючого людину середовища. У Декларації містяться 26 принципів захисту довкілля, до яких належать такі як:

1) людина має основне право на свободу, рівність і сприятливі умови довкілля, якість якого дає змогу вести гідне i процвітаюче життя, і несе головну відповідальність за охорону і поліпшення навколишнього природного середовища на благо нинішнього і майбутніх поколінь, що вимагає подолання будь-яких проявів політики расизму, дискримінації, апартеїду тощо;

2) принцип забезпечення безпеки використання природних ресурсів, у тому числі вжиття заходів з їх відновлення шляхом оптимізації здійснення публічного управління та контролю;

3) принцип впровадження відновлювальних джерел виробництва енергіі;

4) принцип невідворотності відповідальності людини за збереження природних ресурсів та природних об'єктів;

5) принцип раціонального використання невідновлювальних природних ресурсів;

6) принцип підвищеної відповідальності за забруднення довкілля та невжиття заходів зі зменшення шкідливого токсичного впливу на нього;

7) принцип запобігання поширенню порушень, пов'язаних із забрудненням морів та знищенням водних живих ресурсів;

8) принцип пріоритетності соціально-економічного розвитку суспільства, результатом якого має бути забезпечення гідного рівня життя людини;

9) принцип міжнародного співробітництва у сфері запобігання та ліквідації наслідків екологічних стихійних лих та катастроф;

10) принцип поєднання економічної вигоди та раціонального використання природних ресурсів;

11) принцип підтримки інноваційного розвитку суспільства у сфері охорони навколишнього природного середовища;

12) принцип підтримки країн, що належать до країн, що розвиваються, з урахуванням необхідності задоволення їхніх економічних та природоресурсних потреб; 
13) принцип сталого розвитку суспільства, держави та природи;

14) принцип раціонального використання природних ресурсів;

15) принцип впровадження благоустрою населених пунктів з метою вирішення задачі забезпечення гідного рівня життя людини і суспільства в цілому;

16) принцип забезпечення ефективної демографічної політики, реалізація якої не заподіює шкоди навколишньому природному середовищу;

17) принцип наукової обґрунтованості управлінських рішень у сфері захисту довкілля;

18) принцип сприяння впровадженню науково-технічного прогресу з урахуванням потреб забезпечення захисту довкілля;

19) принцип обов'язковості екологічної освіти населення незалежно від вікового критерію;

20) принцип міжнародної підтримки науково-дослідних екологічних проєктів;

21) принцип самостійності визначення змістового наповнення внутрішньої державної політики у сфері охорони та захисту довкілля та її здійснення;

22) принцип вжиття заходів із забезпечення механізмів компенсації заподіяної шкоди довкіллю;

23) принцип урахування особливостей національної самоідентифікації у визначенні критеріїв правомірності діяльності у сфері захисту довкілля;

24) принцип рівності суб'єктів механізму захисту довкілля;

25) принцип динамічності у визначенні правового регулювання механізмів відповідальності у сфері захисту довкілля;

26) принцип міжнародного співробітництва у сфері поступової відмови від використання та виробництва зброї масового знищення людей [14].

Варто виділити ще низку міжнародних нормативно-правових актів у сфері захисту довкілля, що ратифіковані Верховною Радою України і впроваджуються ії системою органів публічного управління. Такими актами $\epsilon$ Орхуська конвенція [15], Конвенція ООН по боротьбі із засухою; Конвенція з біорізноманіття; Рамочна конвенція з охорони та збалансованого розвитку Карпат; Конвенція про міжнародну торгівлю видами дикої фауни та флори, що перебувають під загрозою вимирання; Конвенція про збереження мігруючих видів диких тварин (Боннська конвенція); Конвенція із захисту Чорного моря від забруднення; Європейська ландшафтна конвенція; Конвенція про охорону дикої флори та фауни, а також природного середовища в Європі (Бернська конвенція) [16].

Крім того, актуальності набуває ратифікований «Протокол про стратегічну екологічну оцінку» (Протокол про (EО) до Конвенції про оцінку впливу на навколишнє середовище у транскордонному контексті (Kонвенція Еспо), ратифікований Верховною Радою України (№ 562-VIII від 01.07.2015) [17], та «Директива 2001/42/ ЄC про оцінку впливу окремих планів і програм на навколишнє середовище» (Директива ЄС про CEO) [18], імплементація якої належить до однієї з першорядних задач реалізації вимог Угоди про асоціацію між Україною та ЄC $[19 ; 20]$.

Варто відзначити, що Україною ратифіковано понад двадцять міжнародних програмних документів, зміст яких передбачає вжиття заходів з охорони та захисту довкілля.
До системи нормативно-правового регулювання відносин у сфері захисту довкілля відповідно до положень Закону України від 23 лютого 2006 року № 3477-IV «Про виконання рішень та застосування практики Європейського суду з прав людини» [21] належать і рішення ЄСПЛ.

Зокрема, у справі «Тургут та інші проти Туреччини» ЄСПЛ виніс рішення від 08.07.2008 р. щодо доцільності знесення будинку, що знаходився в межах прибережної морської смуги, незважаючи на наявність дозволу на використання таких земель, а також незважаючи на забезпечення власниками будівлі доступу громадськості до узбережжя [22], при цьому зазначивши, що з метою досягнення балансу особистого та публічного інтересів уряд Туреччини має виплатити компенсацію вилученого нерухомого майна.

Висновки. Залишається невирішеною проблема гармонізації вітчизняного законодавства з питань застосування заходів адміністративної відповідальності відповідно до міжнародних та європейських стандартів. Зокрема, надзвичайно «болючим» $є$ питання кодифікації адміністративно-деліктного законодавства України.

Здійснення діяльності із систематизації адміністративно-деліктного законодавства переслідує мету сприяння підвищенню ефективності правореалізації та правозастосування, що своїм неминучим результатом має формування належного рівня правової культури та правової активності громадськості [23, с. 10-11; 24, с. 414]. Безумовним прогресивним наслідком систематизації законодавства загалом i адміністративно-деліктного законодавства зокрема $\epsilon$ подолання наявних правових колізій у вітчизняній системі права.

\section{Література}

1. Улютіна О.А. Адміністративно-правові засади охорони навколишнього природного середовища та природокористування : дис. ... канд. юрид. наук : 12.00.07. Київ : Нац. ун-т біоресурсів і природокористування України, 2011. 209 с.

2. Про Основні засади (стратегію) державної екологічної політики України на період до 2030 року : Закон України від 28 лютого 2019 року № 2697-VIII. Відомості Верховної Рaдu. 2019. № 16. Ст. 70.

3. Про державне регулювання видобутку, виробництва і використання дорогоцінних металів і дорогоцінного каміння та контроль за операціями з ними : Закон України від 18 листопада 1997 року № 637/97-ВР. Відомості Верховної Ради України. 1998. № 9. Ст. 34.

4. Гірничий закон України від 6 жовтня 1999 року № 1127-XIV. Відомості Верховної Ради України. 1999. № 50. Ст.433.

5. Про заборону на проведення суцільних рубок у гірських ялицево-букових лісах Карпатського регіону : Закон України від 10 лютого 2000 року № 1436-III. Відомості Верховної Ради України. 2000. № 13. Ст. 99.

6. Про Програму створення і використання матеріальних резервів для запобігання, ліквідації надзвичайних ситуацій техногенного та природного характеру та їх наслідків у Дніпропетровській області до 2022 року : Рішення Дніпропетровської обласної ради від 24.04.2003 р. № 137-8/ XXIV URL: http://oblrada.dp.gov.ua/region-programmes/.

7. Довгострокова програма з вирішення екологічних проблем Кривбасу та поліпшення стану навколишнього природного середовища на 2011-2022 роки : затв. рішенням Дніпропетровської обласної ради від 29.04.2011 р. № 110-6/VI. URL: http://oblrada.dp.gov.ua/regionprogrammes/. 


\section{Правове забезпечення адміністративної реформи}

8. Легеза Ю.О. Напрями розвитку нормативних засад публічного управління у сфері використання природних ресурсів. Юридичний науковий електронний журнал. 2017. № 4. С. 90-93.

9. Про правовий режим території, що зазнала радіоактивного забруднення внаслідок Чорнобильської катастрофи : Закон України від 27.02.1991 р. (зі змінами і допов.). Відомості Верховної Ради УРСР. 1991. № 16. СТ. 198.

10. Про статус i соціальний захист громадян, які постраждали внаслідок Чорнобильської катастрофи : Закон України від 28.02.1991 р. (зі змінами і допов.). Відомості Верховної Ради УРСР. 1991. № 16. Ст. 200.

11. Про використання ядерної енергії та радіаційну безпеку : Закон України від 08.02.1995 р. (зі змінами і допов.). Відомості Верховної Ради України. 1995. № 12. СТ. 81.

12. Про формування Фонду для здійснення заходів щодо ліквідації наслідків Чорнобильської катастрофи та соціального захисту населення : Закон України від 20.06.1997 р. (зі змінами і допов.). Відомості Верховної Ради України. 1997. № 36. СТ. 229.

13. Конституція України : прийнята на п'ятій сесії Верховної Ради України 28 червня 1996 р. Відомості Верховної Ради України. 1996. № 30. Ст. 141.

14. Декларация Конференции Организации Объединённых Наций по проблемам окружающей человека среды (Стокгольм, 1972 г.). URL: https://zakon.rada.gov. ua/laws/show/995_454.

15. Конвенція про доступ до інформації, участь громадськості в процесі прийняття рішень та доступ до правосуддя з питань, що стосуються довкілля (Орхуська конвенція) від 25.06.1998 р. : ратиф. Україною 06.07.1999 р. Офіційний вісник України. 2010. № 33. С. 12. Ст. 1191.

16. Екологічне законодавство України : зб. нормат.-прав. актів станом на 1 вересня 2007 р. Київ : Істина, 2007. $384 \mathrm{c}$.

17. Протокол про стратегічну екологічну оцінку (Протокол про CEO) до Конвенції про оцінку впливу на навколишнє середовище у транскордонному контексті
(Конвенція Еспо), ратифікований Верховною Радою України (Закон України № 562-VIII від 01.07.2015р.). URL: https://zakon.rada.gov.ua/laws/show/995_b99.

18. Директива 2001/42/ЄС про оцінку впливу окремих планів і програм на навколишнє середовище. URL: http://enref.org/docs/dyrektyva-2001-42-es-pro-otsinkuvplyvu-okremyh-planiv-ta-prohram-na-navkolyshnjeseredovysche/.

19. Додаток до Угоди про Асоціацію між Україною, з однієї сторони, та Європейським Союзом, Європейським співтовариством з атомної енергії і їхніми державами-членами, з іншої сторони. URL: http://zakon2.rada.gov.ua/ laws/show/984_a11.

20. Додаток XXX до глави 6 «Навколишнє природне середовище» до розділу 5 «Економічне і галузеве співробітництво» до Угоди про асоціацію України з Європейським Союзом. URL: http://www.kmu.gov.ua/docs/EA/Annexes_ title_V/30_Annex.pdf.

21. Про виконання рішень та застосування практики Європейського суду з прав людини : Закон України від 23 лютого 2006 року № 3477-IV. Відомості Верховної Ради України. 2006. № 30. Ст. 260.

22. Рішення Європейського суду з прав людини у справі «Тургут та інші проти Туреччини»» від 08.07.2008 р. Застосування Європейської конвенції з прав людини для захисту екологічних прав та довкілля (посібник) / $\epsilon$. Алексєєва, О. Мелень-Забрамна, Д. Скрильніков, Видавництво «Компанія «Манускрипт», Львів, 2016. С. 166-170.

23. Теорія права і держави : підручник / кол. авт. : А.С. Васильєв та ін. Харків : ТОВ «Одіссей», 2007. 448 с.

24. Болокан І.В. Реалізація норм адміністративного права : проблемні питання теорії та практики : дис. ... д.ю.н. : 12.00.07. Запоріжжя, 2017. 549 с.

Хижня Л. $\epsilon .$, здобувач кафедри адміністративного та господарського права Запорізького національного університету 